\title{
"The effect of patronage buying motives on small business profitability: evidence from Indonesia"
}

\begin{tabular}{|c|c|}
\hline \multirow{9}{*}{ AUTHORS } & Chalarce Totanan (D https://orcid.org/0000-0003-1988-3109 \\
\hline & R https://publons.com/researcher/4319093/chalarce-totanan/ \\
\hline & Arung Gihna Mayapada (D https://orcid.org/0000-0002-6135-0667 \\
\hline & R https://publons.com/researcher/4174445/arung-gihna-mayapada/ \\
\hline & Nina Yusnita Yamin (D https://orcid.org/0000-0003-0493-0101 \\
\hline & R https://publons.com/researcher/4321864/nina-yusnita-yamin/ \\
\hline & Ni Made Suwitri Parwati (D https://orcid.org/0000-0001-6209-0193 \\
\hline & Rahayu Indriasari (D https://orcid.org/0000-0002-0643-3865 \\
\hline & R https://publons.com/researcher/4321699/rahayu-indriasari/ \\
\hline ARTICLE INFO & $\begin{array}{l}\text { Chalarce Totanan, Arung Gihna Mayapada, Nina Yusnita Yamin, Ni Made } \\
\text { Suwitri Parwati and Rahayu Indriasari (2021). The effect of patronage buying } \\
\text { motives on small business profitability: evidence from Indonesia. Innovative } \\
\text { Marketing, 17(1), 109-119. doi:10.21511/im.17(1).2021.09 }\end{array}$ \\
\hline DOI & http://dx.doi.org/10.21511/im.17(1).2021.09 \\
\hline RELEASED ON & Wednesday, 24 March 2021 \\
\hline RECEIVED ON & Friday, 29 January 2021 \\
\hline \multirow[t]{2}{*}{ ACCEPTED ON } & Wednesday, 17 March 2021 \\
\hline & $(\mathrm{ccc)}$ EY \\
\hline LICENSE & $\begin{array}{l}\text { This work is licensed under a Creative Commons Attribution } 4.0 \text { International } \\
\text { License }\end{array}$ \\
\hline JOURNAL & "Innovative Marketing " \\
\hline ISSN PRINT & $1814-2427$ \\
\hline ISSN ONLINE & $1816-6326$ \\
\hline PUBLISHER & LLC "Consulting Publishing Company "Business Perspectives" \\
\hline FOUNDER & LLC "Consulting Publishing Company "Business Perspectives" \\
\hline
\end{tabular}

NUMBER OF REFERENCES

46
NUMBER OF FIGURES

0
NUMBER OF TABLES

2

(C) The author(s) 2021. This publication is an open access article. 


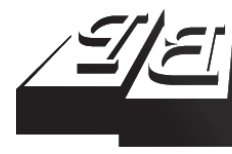

\section{BUSINESS PERSPECTIVES}

LLC "CPC "Business Perspectives"

Hryhorii Skovoroda lane, 10, Sumy, 40022, Ukraine

www.businessperspectives.org
Received on: $29^{\text {th }}$ of January, 2021 Accepted on: $17^{\text {th }}$ of March, 2021 Published on: $24^{\text {th }}$ of March, 2021

(c) Chalarce Totanan, Arung Gihna Mayapada, Nina Yusnita Yamin, Ni Made Suwitri Parwati, Rahayu Indriasari, 2021

Chalarce Totanan, Lecturer, Faculty of Economic and Business, Department of Accounting, University of Tadulako, Indonesia. (Corresponding author)

Nina Yusnita Yamin, Lecturer, Faculty of Economic and Business, Department of Accounting, University of Tadulako, Indonesia.

Arung Gihna Mayapada, Lecturer, Faculty of Economic and Business, Department of Accounting, University of Tadulako, Indonesia.

Ni Made Suwitri Parwati, Lecturer, Faculty of Economic and Business, Department of Accounting, University of Tadulako, Indonesia.

Rahayu Indriasari, Lecturer, Faculty of Economic and Business, Department of Accounting, University of Tadulako, Indonesia.
Chalarce Totanan (Indonesia), Arung Gihna Mayapada (Indonesia),

Nina Yusnita Yamin (Indonesia), Ni Made Suwitri Parwati (Indonesia), Rahayu Indriasari (Indonesia)

\section{THE EFFECT OF PATRONAGE BUYING MOTIVES ON SMALL BUSINESS PROFITABILITY: EVIDENCE FROM INDONESIA}

\begin{abstract}
This study aims to find and analyze the profitability level of Fried Onion Small Business in Palu City, influenced by Patronage Buying Motives (PBM), which consist of company reputation, location of sales, selling price and guarantee to profitability. The population of this study was 52. Population was chosen based on small business that still survives in fried onion business as a local business. The sample taken by purposive sampling was 35 . Data collection was carried out by distributing questionnaires to the managers of fried onion small businesses. The analytical tool used is multiple linear analysis. The results shows that F test of PBM had a significant influence on profitability at 0,822 or $82.2 \%$. This means a very strong influence of the value of PBM. T-test shows that corporate reputation is of significant value of 0,286 , location of sales $-0,426$, and selling price has a significant value of the 0.235 influence on profitability, except guarantees that do not affect profitability because the value of 0.151 is less than the $t$ table value of 2.0395. The impact of this study implies that small food businesses do not really need a guarantee like electronic products, because reputation and quality have become their guarantee.
\end{abstract}

\section{Keywords}

company reputation, location of sales, selling prices, guarantee, profitability, local business

\section{JEL Classification $\quad$ M31, M40, M20}

\section{INTRODUCTION}

Small business is the backbone of any economy and the largest employment opportunities in every country (Eggers, 2020). They also play an important role in increasing people's income because they open jobs for communities. In addition, they play an important role as a source of foreign exchange income for the country.

When the COVID-19 pandemic hit the world, small businesses were the most affected by the lockdown policy (Lu et al., 2020). In addition, the lack of resources has only exacerbated the current situation (Carballero-Morales, 2021). Many small businesses face running out of cash because they have to keep paying a number of expenses while having no income. Research results (Cowling et al., 2020) reveal that $61 \%$ of small businesses are at risk of running out of cash, including $8.6 \%$ that do not have retained earnings. The results of another study in China revealed that $80 \%$ of small businesses were temporarily closed during the COVID-19 pandemic due to logistical restrictions, reduced workforce and reduced demand (Dai et al., 2021). Therefore, the crisis that hit the global economy at this time can be interpreted as a crisis that hit small businesses and their employees. 
The Ministry of Cooperatives, Small and Medium Enterprises (Micro Small Enterprises) of Indonesia recorded 1,417 small businesses affected by COVID-19, of which $68 \%$ were due to decreased sales, $14 \%$ due to difficulty obtaining capital, $9 \%$ due to late operations and distribution, 5\% due to difficulties in obtaining raw materials, and the rest due to delayed production. Research results by Lutfi et al. (2020) show that social distancing policies have a significant impact on small businesses in Indonesia in terms of decreasing income and demand, and increasing raw material costs and production costs. Protection from the government sometimes needed to make a business, especially small businesses can keep operating and survive (Tandirerung et al., 2019). Government of Indonesia gives subsidies as one of the ways to help small business stay on running.

The Central Sulawesi Province in Indonesia, in particular Palu City, has a superior product of local endemic onions. Small business of fried onions is one of the underdeveloped processing industries. In 2018, out of 52 small and medium enterprises, fried onions are still limited to household businesses with a workforce between 3-10. This business is a souvenir business that depends on the tourism sector. However, the COVID-19 pandemic has closed a number of tourist attractions and decreased the number of tourists significantly.

Until now, patronage buying motives are research variables that are only associated with interests or purchasing decisions by consumers and have never been associated with company profitability. Profitability is always assessed in terms of assets owned by the company and has not been linked to the marketing side of a product. Accounting research itself rarely involves variables outside accounting to see the level of profitability of the company. The research conducted by Totanan (2018) proves that patronage buying motives affect the going concern principle, but have not yet entered the realm of profitability. Even though profitability is one part that can make a company to maintain its business continuity and fulfill the concept of going concern in accounting.

The expected contribution of this study is to find empirical evidence that the profitability of an entity is not only influenced by accounting variables such as assets, but one of the factors is influenced by patronage buying motives, which consist of the company's reputation, sales location, selling price, and guarantee.

\section{LITERATURE REVIEW AND HYPOTHESES}

Profit is the result of a summary of calculating business operations in a certain period of time. Profit is part of company information that is most in demand by stakeholders. Profit aims to provide measurements of changes in owner or stakeholder wealth over a period and estimations of current business profitability, namely to what extent the business can cover its operational costs and obtain returns for its shareholders or owners (Subramanyan, 2017).

Profit is so important not only for the owner or investor, but even for everyone who has an interest in businesses. Profit is defined as income and profit after deducting expenses and losses. Profit based on the accrual accounting concept is cur- rently associated as a measurement of operating activities. This is what Subramanyan (2017) said that the role of earnings as an indicator and an important element of profitability is very important, especially for analysis because profit helps in estimating the future profit potential of a business. That is, without company profits it is considered not to have a future and will soon be out of the operation, not be going concern.

To measure the future of the company, information on profitability is needed. Profitability is defined as a company's ability to earn profits or profits from its business (Sunyoto, 2013). According to Subramanyan (2017), profitability is seen as an illustration of returns on capital or investment and will be a long-term financial strength. Analysis of profitability can also be an important basis of planning and controlling business activities. 
To achieve profitability, small fried onion enterprises need an analysis of Patronage Buying Motives as variables that affect profitability. This is based on the concept of survival of each business, depending on the pattern of consumer shopping and the factors that motivate them in the environment in which they survive (Moebarak, 2009; Setiadi, 2003). Consumers are not an accounting business. But a company can never make a profit and operate without consumers. Therefore, keeping loyalty must be insightful of profitability, and one of the ways is through the patronage buying motives.

The importance of focusing on patronage buying motives is because the future of earnings is covered by contingency (Subramanyan, 2017). Why are the numbers of profits or losses for a company so important? Because in the event of a large profit distortion, this will create its own fears for managers, owners, or investors. This means that their intrinsic values in the profit rate that are reflected as performance values.

Elements of patronage buying motives are of the motivation why consumers buy a product or why they consume it. The elements in this study are: company reputation, location of sale, selling price, and guarantee. Patronage Buying Motives are part of the company's internal that influences consumer decisions to buy (Totanan, 2018; Weinstein \& Kelling, 2007). These elements are a consideration for consumers to buy or consume a product that is available, even though the product is not a basic necessity or is only a souvenir (local foods) from the one place.

The next is the reputation or good name of a company. Reputation is a picture of mind frame for an entity. This picture will be an image for someone. This image can be bad (negative), it can also be good (positive). The main aspects of a company's reputation are leadership, product and service quality, financial performance, staff service, environmental responsibility and social responsibility (Sanjaya \& Elsye, 2016).

According to Erkmen and Esen (2014), reputation is an important asset for an organization. Sanjaya and Elsye (2016) also believed that the company's reputation is the perception of all stakehold- ers. These stakeholders can be employees, investors, competitors, creditors, and even consumers. The company's reputation is an award obtained by the entity because of the advantages of the company, which is its ability so that the company will continue to create new things to meet consumer needs (Aryska, 2017; Erkmen \& Esen, 2014; Peter \& Olson, 2013).

The reputation dimension can include merchandise, services, clients, physical facilities, promotion and convenience (Peter \& Olson, 2013; Sanjaya \& Elsye, 2016). However, the most frequently studied from the company's reputation is a product in terms of product quality and price, as well as from services with satisfaction, ease of shopping. The reputation of the company is part of goodwill, identity, image, brand, and prestige in an organization (Putri \& Hatane, 2016). Companies with good reputations are better to maintain profits.

One of the business successes is determined by the company location. The location of a company can affect distribution costs, market potential, ease of access, and access to sales. Site selection can reduce low distribution costs and the possibility of obtaining optimal profits (Muhardi, 2011). Alma (2009) states that locations are affected, among others by: 1) Consumer demographic characteristics, 2) Local economic conditions, 3) Population and income conditions, 4) Competition, and 5) Social climate and trade.

The location in this study is defined as a place where the business is located. The location criteria that are considered good so far are strategic, easy to reach, and safe locations. For a number of consumers who emphasize their purchases in a more strategic or more easily accessible place, parking is also a consideration (Swastha, 2000, 2002). The importance of location to increase company sales directly will affect business profitability in the future (Peter \& Olson, 2013). Therefore, with the sales increase, the company's revenue will automatically increase. So, profitability will increase.

Price is one of the important elements in sales and will determine the level of income. To reach the maximum level of sales, pricing must be moderated. Prices reflect the value, quality, and benefits of a product offered by a company (Kotler \& 
Armstrong, 2008; Wijaya, 2014). Another indicator is competitiveness due to price. Price is also one of the factors that can influence consumer decisions to buy a product. On the other hand, price is also a measure of the value of a person's satisfaction on the product bought and expressed in units of currency (Sunyoto, 2013). Companies must be able to set a selling price policy appropriately because it can affect sales. The purchase price is expected to cover all operational costs and earn profits (Tohar, 2000).

Guarantee means warranty. Guarantees for fried onion products are related to the quality of products offered by business actors. Guarantees can also be one of the factors that influence consumer choice. Generally, quality assurance is always emphasized when offering a product to consumers. Guarantees are generally in after-sales service, specifically on fixed assets with the long-term use (Royan, 2011). For customers, guarantees protect them from buying defective products and can increase customer satisfaction. In addition, the company utilizes the guarantee as an effective promotional tool because products with a longer guarantee period signal to customers that the product has good quality (Royan, 2011; Wijaya, 2014).

For food products such as Palu fried onions, the guarantee can be in the form of a damaged product replacement and product quality guarantee. Quality assurance itself is the quality standard that the product has. Customers will feel happy and believe about a product. This guarantee will automatically lead to trust in the company compared to the situation when consumers buy products without quality assurance. Warranty can provide a sense of security to consumers for the use of products they buy. Very likely, dissatisfaction will arise in customers moving to competitors. What is more, dissatisfaction due to the failure of the warranty will be stored in the minds and hearts of consumers. So, it is not easy to win them.

Based on the description above, this study aims to find and analyze the effect of company reputation, location of sales, selling price, and guarantee as sub-variables of patronage buying motives on profitability. The focus is on fried onion small business in Palu city. Hypotheses of this study are formulated as follows:
H1: Company reputation has a significant effect on profitability.

H2: Sales location has a significant effect on profitability.

H3: Selling price has a significant effect on profitability.

H4: Guarantee has a significant effect on profitability.

\section{RESEARCH METHODS}

This study uses survey methods and is verificative. The survey was conducted on 52 fried onion small enterprises in Palu, with the Department of Industry and Trade of Palu City (2017) as a population. The population is defined as a generalization area consisting of objects/subjects that have certain qualities and characteristics determined by researchers; the conclusions were studied and then drawn (Sugiyono, 2014). There were only 35 that still existed, 17 are no longer active for various reasons, among other things, due to disasters, capital outflows, and also because of unsustainable raw material supplies. The indicators of the research variables can be seen in Table 1 .

The data used in this study are primary data and secondary data. Primary data is collected through questionnaires, while secondary data is obtained through documents from media sourced, documents and journals related to this research. The data obtained is then processed using the SPPS 25 program. The data processing results will be analyzed using multiple linear regression to test the hypotheses suggested above.

Table 1. Variable indicators

\begin{tabular}{|c|c|c|}
\hline Variables & Indicator & Scale \\
\hline $\begin{array}{l}\text { Company } \\
\text { reputation }\left(X_{1}\right)\end{array}$ & $\begin{array}{c}\text { Product quality, product variety, } \\
\text { service }\end{array}$ & Ordinal \\
\hline Sales location $\left(X_{2}\right)$ & Strategic location, easy to reach & Ordinal \\
\hline Price $\left(X_{3}\right)$ & $\begin{array}{l}\text { Price compatibility, purchasing } \\
\text { power, competitiveness of price }\end{array}$ & Ordinal \\
\hline Guarantee $\left(X_{4}\right)$ & $\begin{array}{l}\text { Product standard, replacement of } \\
\text { damaged }\end{array}$ & Ordinal \\
\hline Profitability $(Y)$ & Sales, assets, capital, investment & Ordinal \\
\hline
\end{tabular}




\section{EMPIRICAL RESULTS}

The fried onion industry processes cooked readymade onions for fried onions using the process, stripping, slicing, frying, oil drying and packaging. Through this process, the industry has used frying and packaging and drying production machines for those with a lot of capital. Oil drying is one of the steps that contribute to improve the quality of fried onion products. At that stage, chemical hazards from cooking oil can be reduced or removed (Jayadi et al., 2018).

Validity and reliability testing by the SPSS for Windows version 25.0 program is done to determine the level of accuracy or reliability of research instruments. Validity refers to Karl Pearson's assumptions and reliability tests using Cronbach Alpha (a) statistical test techniques with Cronbach Alpha criteria $>0.60$ (Ghozali, 2006, 2016). All statement items from each independent variable $X$ and dependent variable $Y$ show valid and reliable results. Classical assumption testing is done to find out whether the regression coefficients obtained can be accepted, and avoid the possibility of violations of classical assumptions, which are the basic assumptions in regression analysis (Ghozali, 2013).

Multiple linear regression analysis is used to find out how the dependent variable can be predicted through more than two independent variables as a predictor factor. The results of multiple regression are in Table 2.

The coefficient of determination is seen in Adjusted $\mathrm{R}$ Square because there are more than three independent variables. This value of 0.822 means that the variation of the patronage buying motives can explain the variation in the profitability variable of fried onion small business by $82.2 \%$. It means that the $17.8 \%$ influence by other variables that have not been included in the patronage buying motives variable is seen in the regression equation model.

In the multiple $R$ correlation coefficient of 0.918 , it means that there is a positive relationship between the variables in patronage buying motives, which explains the variation in the profitability variable small business of fried onion in Palu City by $91.8 \%$. From the results of data processing, the following regression equation is obtained:

$$
\begin{aligned}
& Y=-4.152+0.267 X_{1}+0.497 X_{2}+ \\
& +0.305 X_{3}+0.217 X_{4} .
\end{aligned}
$$

The $b_{0}$ constant of -4.152 shows that without patronage buying motives, the profitability of the company will be at the minimum level. This means that the patronage buying motives variable has a very strong influence on the profitability of fried onion small business in Palu City.

This regression coefficient values of $b_{1}, b_{2}, b_{3}$, and $b_{4}$ give the meaning of finding a positive relationship between company reputation of 0.267 , sales location of 0.497 , selling price of 0.305 , and guarantee of 0.217 , with profitability where each increase in independent variables will have an impact on increasing profitability. Each addition of one company reputation will increase profitability by 0.267 , assuming that other independent variables do not change. The same assumption applies if the influence of the company's location up one will increase profitability by 0.497 . For the effect of selling prices, if both indicators will increase profitability by 0.305 , and guarantee as the smallest independent variable, then profitability will increase by 0.217 for each addition of one guarantee.

\begin{tabular}{|c|c|c|c|c|c|}
\hline No. & Independent variable & $\begin{array}{l}\text { Coefficient } \\
\text { Regression } \\
\end{array}$ & $t$-count & Sig. & $r$-partial \\
\hline 1. & Company reputation $\left(X_{1}\right)$ & 0.267 & 2.861 & 0.008 & 0.463 \\
\hline 2. & Sales location $\left(X_{2}\right)$ & 0.497 & 4.262 & 0.000 & 0.614 \\
\hline 3. & Price $\left(X_{3}\right)$ & 0.305 & 2.345 & 0.026 & 0.394 \\
\hline 4. & Guarantee $\left(X_{4}\right)$ & 0.217 & 1.513 & 0.141 & 0.266 \\
\hline \multicolumn{2}{|l|}{ Constants $=-4,152$} & \multicolumn{2}{|c|}{$F$ count $=40.188$} & \multicolumn{2}{|c|}{ Sig. $F=0.000$} \\
\hline \multirow[t]{2}{*}{ Multiple $R=0,918$} & & \multicolumn{2}{|c|}{$R$ Square $=0.843$} & \multirow{2}{*}{\multicolumn{2}{|c|}{$\alpha=0.05$}} \\
\hline & \multicolumn{2}{|c|}{ Adjusted $R$ Square $=0.822$} & & & \\
\hline
\end{tabular}

Table 2. Multiple linear regression calculation results 
The $F$-test is conducted to determine whether the independent variable $X$ has a significant effect on the dependent variable $Y$. Based on the results of the ANOVA (Analysis of Variance) or $F$ test, the $F$ count is $40.188>F$ table of 2.68 , and the significance level is smaller than the level of distrust $0.000<0,05$. The results of the test mean that patronage buying motives influence profitability so that the company's reputation, location of sales, selling price and guarantee simultaneously are thought to have a significant effect on profitability.

The $t$-test is conducted to find out whether every $X$ variable in the patronage buying motives has a significant influence on or contribution to the $Y$ variable. The results of the $t$ test statistic of the four independent variables in the regression model show that:

a) The $t$ count of corporate reputation is greater than $t$ table $(2.861>2.0395)$, and the significance level is smaller than the confidence level of $5 \%(0.008<0.05)$. The value means that the company reputation variable has a significant effect on profitability. So $\mathrm{Hl}$, which states that the company's reputation has a significant effect on profitability, is accepted.

b) The $t$ count value of the sales location is greater than $t$ table $(4.262>2.0395)$, and the significance level is smaller than the confidence level of $5 \%(0,000<0.05)$. This means that location sales variables have a significant effect on profitability. Therefore, $\mathrm{H} 2$, which states that the location of sales has a significant effect on profitability, is accepted:

c) The $t$ count value of the selling price is greater than $t$ table (2.345> 2.0395), and the significance level is smaller than the confidence level of $5 \%(0.026<0.05)$. This value gives the meaning that the selling price variable has a significant effect on profitability. Finally, it can be concluded that $H 3$, which states that the selling price has a significant effect on profitability, is accepted.

d) The guarantee value is smaller than $t$ table $(1.513<2.0395)$, and the significance level is greater than the confidence level of 5\% (0.141> $0.05)$. This means that product guarantee var- iables do not affect profitability. Therefore $H 4$, which states that the guarantee has a significant effect on profitability, is rejected.

Based on the results of this study, which examined the influence of the company's reputation, location of sale, selling price and guarantee of fried onion product small business in the city Palu, there are several things that can be explained in this study.

\section{DISCUSSION}

The small business problem can be the same anywhere in the world. The main problem of small businesses it to survive, provided that capital and profits do not increase, especially during the COVID-19 pandemic. According to Ajara (2017), patronage buying motives is the reason that motivated buyer to decide to purchase a product. Palu city has 35 shops that sell fried onions so that buyers may compare a particular fried onion shop in preference. Rachman (2006) proves that the company's reputation influences marketing performance. If marketing performance increases, sales will increase. At the end of the sales, performance will be directly correlated with the profitability. This is supported by Yani and Endang (2015) who state that the company's reputation influences consumer purchasing decisions. The decision to buy will also lead to the company's profitability. Reputation or branding effect positively impact the quality perceptions of consumers, and it was also found that seller's reputation has an impact on the perceived value of customers of purchase decision-making (Bianchi, Bruno, \& Sarabia-Sanchez, 2019; Laja, 2020; Vafadarnikjoo et al., 2018).

Kotler and Amstrong (2012) said that the placement of a strategic location is an important thing. The decision about location sales must consider the potential for economic growth and stability, competition, and potential climate (Noersyeha \& Sosianika, 2018; Sosianika \& Najib, 2018). Ghanimata (2012) proves that the location of sales is a variable that most influences the tendency of consumers to buy a product. This is supported by Totanan (2018) that the location of sales influences the going concern principle. 
The price is also to the basis for achieving the profitability. The results of this study indicate that price affects profitability. Other studies prove that selling prices affect an increase in sales of a company's products (Ginting et al., 2014; Totanan, 2018; Yuliati, 2011). Instead, this study found that the guarantee of fried onion products as local food did not affect profitability. Product guarantees, in particular, are only halal statements to be things that are also taken by consumers in buying a product. Awan et al. (2015) and Nurhayati and Hendar (2019) have proved that halal product awareness affects halal product purchase intention. Empirically, this is also supported by interviews and respondents' statements that consumers are mostly people who come from the other city. Product guarantees are also related to security for consumption, so that being equipped with an expiration date is one form of guarantee from local food producers.

Knowing patronage buying motives that make consumers choose to buy or use a company's products is very important for small business. Focus and paying attention to patronage buying motives certainly helps business owners in achieving profitability. Understanding consumers buying motives will help in product positioning, gaining competitive advantage. Patronage buying motives are important for increasing profitability. The happier and more loyal a customer to the company, the more income will be added. If high income will have an impact on profitability, even though in accordance with the accounting concept of income (profit) must be matching with costs to obtain the profit. So, to get profitability, consumer factors must be an important concern for every company.

This study proves that company reputation influences the profitability of small business in Palu City. According to Yani and Endang (2015), reputation is represented by the quality of products. Quality and hygienic products are indicators of the company's reputation. This is based on a product or service closely related to the reputation associated with the brand name. In the industry, brands are often associated with the company's reputation. This means that the quality of a product or service is related to the company's reputation, combined with the product brand (Selnes, 1993), specifically for local food products that have distinctive characteristics from other regions. The advantage of these products is that the competencies of local business managing products will be superior compared to other regions.

Company reputation is one of the focuses that influence consumers and interest in buying. Reputation is a basis for attitude and trust in brand, image and taste. Studying factors that influence consumer decisions, it was found that reputation had a positive effect on buying decisions (Gunawan, 2006). Bad products will also have a negative impact on the company's reputation. Once a product is considered good or bad, it will always be attached, remembered and become a consumer image. This means that it is important to understand the factors of a company's reputation that will affect the company's profitability.

The reputation of the company is also one of the company's competitive advantages. The better the company's reputation in the eyes of the market, the more attractive the company's products are, specifically food products. The higher the market interest in the product, the greater the opportunity for companies to increase sales, the more consistently the company make profits. A company with a good reputation also increases its value and makes it easier to set the selling price of the product. The products produced will also be valued higher because the reputation has its own price.

Companies with good reputation are able to potentiate their performance and competitiveness (Ginesti et al., 2018). Referring to the research of Putri and Hatane (2016), corporate reputation has a significant effect on financial performance. According to Sanjaya and Elsye (2016), the company's reputation has an effect on financial performance, besides, there is a direct relationship between the company's reputation and financial performance, even the study also proved that there is a positive and sustained relationship between company reputation and financial performance. One indicator of financial performance is profitability.

The sales location affects the profitability of fried onion small business in Palu City. Consumers strive for a strategic, safe, comfortable company's sales location, and the atmosphere of the place. The right sales location has a positive correlation with profitability. If the company is not right in determining the location of its sale, it will reduce its competitiveness and selling power. This means 
that income can decrease and profitability ratios will also decrease. As a result, in the long run, the company can fail and stop working (Totanan, 2018). That is, the more strategic location of sales will provide maximum profit opportunities for the company, and vice versa. The influence of sales location on the profitability of fried onion small businesses can be one of the benchmarks for increasing the company's profitability. This is supported by Suharti (2006) that the place of sale (like outlet) influences the profitability of the business in Surakarta. Printezis and Grebitus (2018) said that it is important for farmers, marketers, and policy makers to understand consumers' motivation for buying local through various channels.

Empirically, the results of this study found that selling prices affect the profitability of fried onion small business in Palu City. Although the cost components calculated in the cost of goods have not been calculated based on real costs but estimated based on expenditure and compared the existing market prices. This has an effect on the varying selling prices of fried onion products at the same time, especially on big or religious holidays. Because in these seasons there is high demand and the holiday season. Julianti (2015) supports that the selling price affects profitability.

Selling prices as a determinant of the profitability of a business are directly correlated with income. Income is recognized if the company sells goods or hands over services. Not related to when money or cash is received if it is based on the accrual accounting concept. Likewise, the costs are always associated with income received and has not been linked to when the costs are paid.

The selling price also correlates with the quality of goods sold. Consumers tend to compare the selling price with the benefits they will get. Consumer targets are also important considerations in planning selling prices. There are consumers who tend to like low prices, but a few consumers who still choose expensive prices if the product has quality and gives satisfaction.

Guarantees have a positive but not significant effect on the profitability of fried onion small business in Palu City. Some business owners state that they will be responsible for sales errors but not for product returns. This means: the company's reputation, selling price, and sales location are more important than product guarantees. Besides, the most of the population of Palu city is Muslim, so there is little concern for the halal status of products produced here. This result might be different if this study was conducted on non-food products. For example, a guarantee on the purchase of fixed assets. It is understandable if previous research was not in line with this study, since some previous research did find guarantees that affect sales rather than profitability (Rahmatya, 2017; Wijaya, 2014).

\section{CONCLUSION}

Based on the study's aim to find the level of profitability, it was found that three sub-variables of patronage buying motives, such as company reputation, sales location, and selling price, significantly affected the profitability of fried onion small business in Palu City. The influence of the company's reputation on the profitability of a fried onion small business in which consumers consume fried onions because of the image of Palu fried onions, is significant and considered as a necessity. This image makes it easy for a small business to develop strategies to achieve profitability by improving reputation. The fourth variable, guarantee, does not affect the profitability of the fried onion small business in Palu City. Empirically, this shows that food products rarely impose collateral for damage to products that have been purchased by consumers. This will be in contrast to similar electronic products that have long-term functions, where guarantees are an important consideration for consumers when buying a product.

The limitation of this study is for the population that only uses small business of fried onions, so they cannot generalize the results to other small businesses with different products. In addition, fried onions are local agricultural products that follow the season, so the possibility of price stability is not met. Small fried onion businesses are also still traditionally managed and lack a clear organizational struc- 
ture. In addition, inconsistencies with previous research on guarantee variables that have no effect represent opportunities for further research that could be done. This has spurred more attention to quality improvement through clear composition and expiration dates, and the presence of halal labels.

\section{AUTHOR CONTRIBUTIONS}

Conceptualization: Chalarce Totanan.

Data curation: Nina Yusnita Yamin, Arung Gihna Mayapada, Ni Made Suwitri Parwati.

Formal analysis: Chalarce Totanan, Rahayu Indriasari.

Funding acquisition: Nina Yusnita Yamin.

Investigation: Arung Gihna Mayapada, Ni Made Suwitri Parwati.

Methodology: Nina Yusnita Yamin, Rahayu Indriasari.

Project administration: Arung Gihna Mayapada, Ni Made Suwitri Parwati.

Resources: Chalarce Totanan, Nina Yusnita Yamin.

Software: Arung Gihna Mayapada.

Supervision: Chalarce Totanan.

Validation: Ni Made Suwitri Parwati, Rahayu Indriasari.

Visualization: Rahayu Indriasari.

Writing - original draft: Arung Gihna Mayapada, Ni Made Suwitri Parwati.

Writing - review \& editing: Chalarce Totanan, Nina Yusnita Yamin.

\section{REFERENCES}

1. Ajara, R. (2017). The Analysis of Buying Motives in Purchase Decision of Virtual Goods in Online Game. Jurnal EMBA, 5(1), 87-95. Retrieved from https://www. neliti.com/publications/129326/ the-analysis-of-buying-motivesin-purchase-decision-of-virtualgoods-in-online-g

2. Alma, B. (2009). Manajemen Pemasaran dan Pemasaran Jasa (8th ed.). Bandung: Alfabeta. https://cvalfabeta.com/product/ manajemen-pemasaran-danpemasaran-jasa/

3. Aryska, M. (2017). Pengaruh Reputasi Perusahaan danKualitas Pelayanan terhadap Kepuasan Pasien (Kasus Rumah Sakit Islam Ibnu Sina Pekanbaru). Jurnal Ilmu Administrasi, 4(1). Retrieved from https://www.neliti.com/publications/123831/pengaruh-reputasiperusahaan-dan-kualitas-pelayanan-terhadap-kepuasan-pasien-kas

4. Awan, H. M., Siddiquei, A. N., \& Haider, Z. (2015). Factors affecting Halal purchase intention - evidence from Pakistan's Halal food sector. Management Research Review, 38(6), 640-660. https://doi. org/10.1108/MRR-01-2014-0022
5. Bianchi, E., Bruno, J. M., \& Sarabia-Sanchez, F. J. (2019). The impact of perceived CSR on corporate reputation and purchase intention. European Journal of Management and Business Economics, 28(3), 206221. https://doi.org/10.1108/ EJMBE-12-2017-0068

6. Erkmen, T., \& Esen, E. (2014). Work Family, Family Work Conflict and Turnover Intentions Among The Representatives of Insurance Agencies. Journal of Business, Economics and Finance, 3(3), 302-321. Retrieved from https:// www.semanticscholar.org/paper/ Work-Family\%2C-Family-WorkConflict-and-Turnover-the-Erkmen-Esen/ba6c3eb321592771b$05842 \mathrm{ba76c348a92fa83176}$

7. Ghanimata, F. (2012). Analisis Pengaruh Harga, Kualitas Produk, dan Lokasi Terhadap Keputusan Pembelian. Fakultas Ekonomika Dan Bisnis Universitas Diponegoro Semarang. Retrieved from https://core.ac.uk/download/ pdf/11734676.pdf

8. Ghozali, I. (2006). Aplikasi Analisis Multivariae Dengan Program SPSS. Semarang: Universitas Di- ponegoro. Retrieved from http:// library.fip.uny.ac.id/opac/index. php?p=show_detail\&id=3483

9. Ghozali, I. (2013). Aplikasi Analisis Multivariate dengan Program IBM SPSS 21 Update PLS Regresi. Semarang: Badan Penerbit Universitas Diponegoro. Retrieved from https://mikroskil. ac.id/pustaka/index.php?p=show_ detail\&id $=7026 \&$ keywords $=$

10. Ghozali, I. (2016). Aplikasi Analisis Multivariete Dengan Program IBM SPSS 23. (P. P. Harto, Ed.) (8th ed.). Semarang: Badan Penerbit Universitas Diponegoro.

11. Ginesti, G., Caldarelli, A., \& Zampella, A. (2018). Exploring the impact of intellectual capital on company reputation and performance. Journal of Intellectual Capital, 19(5), 915-934. https://doi. org/10.1108/JIC-01-2018-0012

12. Ginting, S., Suryana, L., Jwem, \& Mikroskil, S. (2014). Analisis Faktor-Faktor Yang Mempengaruhi Opini Audit Going Concern Pada Perusahaan Manufaktur Di Bursa Efek Indonesia. Jurnal Wira Ekonomi Mikroskil, 4(02), 71-80.

13. Gunawan. (2006). Pengaruh Rasio Keuangan Terhadap Pertumbuhan 
Laba Pada Perusahaan Perdagangan Di Indonesia. Jurnal IImiah Dan BBsnis, 13(1). Retrieved from http://jurnal.umsu.ac.id/index. $\mathrm{php/mbisnis/article/view/102}$

14. Jayadi. (2018). Product Quality of the Local Fried Onion in Palu City, Indonesia. Indian Journal of Public Health Research \& Development, 9(12), 1431-1437. Retrieved from https://www.researchgate.net/ publication/330826475_Product_ Quality_of the_Local_Fried_Onion_in_Palu_City_Indonesia

15. Julianti, W. (2015). Analisis Pengaruh Biaya Operasional, Harga Jual, dan Volume Penjualan terhadap Profitabilitas pada PT Semen Indonesia (Persero) Tbk. Malang Jawa Timur. Retrieved from http:// mulok.library.um.ac.id/index3. php/68705.html

16. Kotler, P., \& Amstrong, G. (2012). Principles Of Marketing (Edisi 14). New Jersey: Prentice-Hall Published.

17. Kotler, P., \& Armstrong, G. (2001). Prinsip-Prinsip Pemasaran (Alih Bahasa: Damos Sihombing, Ed.) (Edisi Kede). Jakarta: Erlangga.

18. Laja, P. (2020). Purchase Decisions 9 Things to Know About Influencing Customers. Retrieved October 15, 2020, from https://cxl.com/ blog/9-things-to-know-aboutinfluencing-purchasing-decisions/

19. Moebarak. (2009). Alasan Mempelajari Perilaku Konsumen. Retrieved from https://moebarak. wordpress.com/2009/03/06/ alasan-mempelajari-perilakukonsumen/

20. Muhardi. (2011). Manajemen Operasi (1st ed.). Bandung: PT Refika Aditama.

21. Noersyeha, A. G., \& Sosianika, A. (2018). Analysis Buying Motive in Indonesia Football Merchandise Store. Prosiding Industrial Research Workshop and National Seminar, 9, 712-718.

22. Nurhayati, T., \& Hendar, H. (2019). Personal intrinsic religiosity and product knowledge on halal product purchase intention. Journal of Islamic Marketing, 11(3), 603-620. https://doi.org/10.1108/ JIMA-11-2018-0220
23. Peter, J. P., \& Olson, J. C. (2013). Perilaku Konsumen dan Strategi Pemasaran. (D. T. Dwiandan, Ed.) (9 Buku 2). Jakarta: Salemba Empat.

24. Printezis, I., \& Grebitus, C. (2018). Marketing Channels for Local Food. Ecological Economics, 152, 161-171. https://doi.org/10.1016/j. ecolecon.2018.05.021

25. Putri, N. G. A. P., \& Hatane, S. E. (2016). Pengaruh Corporate Reputation terhadap Financial Performance melalui Innovation Capability sebagai Variabel Intervening pada Industri Perhotelan di Surabaya. Business Accounting Review, 4(1). Retrieved from http:// publication.petra.ac.id/index.php/ akuntansi-bisnis/article/view/4177

26. Rachman, S. N. (2006). Analisis Pengaruh Keunggulan Produk, Reputasi PErusahaan dan Asosiasi Merek Terhadap KEsuksesan Produk Baru Dalam Meningkatkan Kinerja Pemasaran (Studi Kasus pada Outlet Penjualan Produk Telkomflexi di Semarang). Universitas Diponegoro Semarang.

27. Rahmatya, A. (2017). Pengaruh Potongan Harga, Garansi dan Variasi Produk terhadap Volume Penjualan Sepeda Motor Honda pada Dealer MPM Motor Pare. Simki-Economic, 01(01). Retrieved from http://simki.unpkediri.ac.id/ detail/13.1.02.02.0213

28. Royan, F. M. (2011). Strategi Sukses Memasarkan Produk Baru. Jakarta: PT Elex Media Komputindo.

29. Sanjaya, F., \& Elsye, S. (2016) Pengaruh Marketing Capabilities terhadap Financial Performance pada Industri Perhotelan di Surabaya dengan Corporate Reputation sebagai Variabel Intervening. Business Accounting Review, 4(1). Retrieved from https://www. neliti.com/publications/183045/ pengaruh-marketing-capabilitiesterhadap-financial-performancepada-industri-per

30. Selnes, F. (1993). An Examination of the Effect of Product Performance on Brand Reputation, Satisfaction and Loy- alty. European Journal of Marketing, 27(9), 19-35. https://doi. org/10.1108/03090569310043179

31. Setiadi, N. J. (2003). Perilaku Konsumen: Perspektif Kontemporer pada Motif, Tujuan, dan Keinginan Konsumen (Revisi). Jakarta: Prenada Media Group.

32. Sosianika, A., \& Najib, M. F. (2018). Retail service quality scale in the context of Indonesian traditional market. International Journal of Business and Globalisation, 21(1), 19. https://doi.org/10.1504/ IJBG.2018.10015254

33. Subramanyan, K. R. (2017). Financial Statement Analysis (11th ed.). Asia: McGraw-Hill Asia.

34. Sugiyono. (2014). Metode Penelitian Kuantitatif Kualitatif. Bandung: Alfabeta.

35. Suharti, S. (2006). Jenis Produk Modal, Tempat Penjualan (Outlet), Pengalaman Kerja dan Promosi terhadap Profitabilitas Usaha Batik di Surakarta. Universitas Muhammadiyah Surakarta.

36. Sunyoto, D. (2013). Analisis Laporan Keungan untuk Bisnis. Yogyakarta: PT Buku Seru.

37. Swastha, B. (2000). Manajemen Pemasaran Modern. Jakarta: PT Raja Grafindo Persada.

38. Swastha, B. (2002). Azas-Azas Pemasaran. Yogyakarta: Liberty.

39. Tandirerung, C. J., Totanan, C., Paranoan, N., Mile, Y., \& Marsuddin. (2019). Perception Of Farmers In Langa Leso Village Towards Subsidies. Journal of Advanced Research in Dynamical and Control Systems (JARDCS), 11(8), 2308-2314. Retrieved from https://www.jardcs.org/abstract. php?id=2975

40. Tohar, M. (2000). Membuka Usaha Kecil. Yogyakarta: Kanisius (Anggota IKAPI).

41. Totanan, C. (2018). Pengaruh Patronage Buying Motives terhadap Prinsip Going Concern pada Industri Rumah Tangga Bawang Goreng di Kota Palu. Akuntansi Akuisisi, 14(1).

42. Vafadarnikjoo, A., Mishra, N., Govindan, K., \& Chalvatzis, K. 
(2018). Assessment of consumers' motivations to purchase a remanufactured product by applying Fuzzy Delphi method and single valued neutrosophic sets. Journal of Cleaner Production, 196, 230-244. https://doi.org/10.1016/j. jclepro.2018.06.037

43. Weinstein, D. R., Kelling, D. G. (2007). "Going Concern", "Deathbed" And Other Unfortunate Metaphors In Avoidance Litigation. ABI Journal, June, 1-7.
44. Wijaya, G. N. A. (2014). Pengaruh Strategi Harga dan Garansi Produk Terhadap Penjualan pada UD Mitra Niaga. Jurnal Ilmu \& Riset Manajemen, 3(4). Retrieved from https:// docplayer.info/33777315-Pengaruh-strategi-harga-dan-garansiproduk-terhadap-penjualan-padaud-mitra-niaga.html

45. Yani, E. S., \& Endang, T. (2015). Kepercayaan Terhadap Keputusan Pembelian Pada Stasiun Stasiun Pengisian Bahan Bakar Umum
(SPBU) Di Kota Semarang. Jurnal Dinamika Sosial Budaya, 17(2), 258-269.

46. Yuliati, U. (2011). Faktor-faktor yang mempengaruhi konsumen dalam pembelian makanan jajan tradisional di kota malang. Jurnal Manajemen Bisnis, 1(01), 7-20. Retrieved from https://www.neliti. com/publications/137987/faktorfaktor-yang-mempengaruhikonsumen-dalam-pembelianmakanan-jajan-tradision 